\title{
Floristic composition and utilization of ethnomedicinal plant species in home gardens of the Eastern Himalaya
}

\author{
Nazir A. Pala ${ }^{1}$, Biplov C. Sarkar ${ }^{1}$, Gopal Shukla ${ }^{1}$, Nakul Chettri ${ }^{2^{*}}$ (D), Shovik Deb ${ }^{3}$, Jahangeer A. Bhat ${ }^{4}$ and \\ Sumit Chakravarty ${ }^{1}$
}

\begin{abstract}
Background: Home gardens are popular micro land-use system and are socioeconomically linked with people for their livelihood. In the foothill region of Eastern Himalaya, very less documentations are available on species richness of the home gardens, particularly on the ethnomedicinal plants. We assumed that the home garden owners of the study site are domesticating ethnomedicinal plants which are not easily accessible to them in the wild due to distant forest. This study was planned to explore and document the diversity and population status of ethnomedicinal plants in the home gardens along with its ethnomedicinal use.
\end{abstract}

Methods: The present study was conducted in the home gardens of Cooch Behar district of West Bengal from May 2017 to May 2018. A multidisciplinary approach like collection of plant specimen, interview with structured questionnaire for documenting the utilization pattern, and quadrat methods for population study was applied. We selected 150 study sites randomly in the village cluster. The owners of the gardens were the respondents for the household survey. The study documented diversity, population size, and medicinal uses of ethnomedicinal plant species identified by the garden owners growing or being grown in their gardens.

Results: A total of 260 plant species were reported, of which, 53 were utilized for different ethnomedicinal applications. These 53 species were represented by 35 families and 45 genera. Most of these ethnomedicinal species were woody perennials (37.73\%). Cocus nucifera dominated the list with highest number of use followed by Hibiscus rosa-sinensis. The use value of the species varied from 0.006 to 0.53 , while the fidelity value (\%) ranged from 2.29 to $93.75 \%$. The leaves of the plants were mostly used for ethnomedicinal applications (19 species) followed by fruits (12 species) and bark (9 species), and the least was the root (7 species). We documented 20 different ailments/diseases cured by using these plants. In some cases, more than one species are used to cure a disease or ailment. As many as 10 species were used to cure only stomach-related problems. Some more diseases like cough and cold and jaundice were treated using six and four species, respectively.

Conclusion: This documented list of 260 plant species including 53 ethnomedicinal ones from the home gardens of the study area indicates that these gardens are key in maintaining diversity and source of healthcare system in agricultural dominant landscape. Documenting such ecological status and traditional applications becomes a prerequisite for developing conservation and management strategies of home gardens to be included in the mainstream conservation processes.

Keywords: Indigenous, Healthcare, Culture, Dominant, Families, Disease

\footnotetext{
*Correspondence: nakul.chettri@icimod.org

${ }^{2}$ International Centre for Integrated Mountain Development (ICIMOD), GPO

Box 3226, Kathmandu, Nepal

Full list of author information is available at the end of the article
}

(c) The Author(s). 2019 Open Access This article is distributed under the terms of the Creative Commons Attribution 4.0 International License (http://creativecommons.org/licenses/by/4.0/), which permits unrestricted use, distribution, and reproduction in any medium, provided you give appropriate credit to the original author(s) and the source, provide a link to the Creative Commons license, and indicate if changes were made. The Creative Commons Public Domain Dedication waiver (http://creativecommons.org/publicdomain/zero/1.0/) applies to the data made available in this article, unless otherwise stated. 


\section{Background}

Home gardens are basic production units contributing to social and cultural well-being in rural areas. These units are becoming dominant and promising land-use system in many part of the tropics that maintain high levels of diversity, productivity, and sustainability endowed with important ecosystem functions [1, 2]. Home gardens have been documented as sources of a diverse and stable supply of goods and services [3-5]. The realization that the home gardens are also a vital reservoir of unique genetic diversity including the ethnomedicinal plants has recently led to more careful research to understand the role of home gardens as in situ genetic diversity [1, 6-11]. The opportunity of using home garden as means for conservation of crop and forest plant genetic diversity as an effective complementary measure to ex situ strategies has been reported [12]. Such traditional knowledge involved in home gardens is not only a cultural heritage but might be highly valuable for many purposes, for instance, to secure the sustainability of gardening or to conserve globally significant agro and medicinal plant diversity [3, 13-15]. Many traditional crop species were reported to have medicinal properties which are retained in the traditional knowledge of the local people through home gardens [16]. Medicinal plants in home gardens are either deliberately cultivated or come up spontaneously as wild and weedy species [2, 17]; they are identified as one of the key characteristics of traditional home gardens $[3,18]$. They have played a major role in maintaining primary and basic healthcare of rural communities from time immemorial $[19,20]$.

On account of high rainfall, rich ethnic diversity, and biodiversity, Cooch Behar district, located in the foothill of North Bengal, has been witnessing a high rate of adoption of home gardens as in other humid areas [1]. Home gardens of Cooch Behar are smaller with an average size of 0.61 ha than that of other parts of India or elsewhere but are generally high in native diversity including ethnomedicinal plants [1, 7-11]. In India, particularly in West Bengal, people living in remote and rural areas are still dependent on traditional medicines for the treatment of various ailments due to lack of modern medical facilities and poor socioeconomic conditions [21-27]. Further, the elders of the region are skeptical on the retention of traditional knowledge and advocate documentation of these old age traditions and domestication of such valuable plant species for renewed interests among new generations and cultural transmissions of this valuable knowledge system [14-29]. Since traditional knowledge on ethnobotany is being eroded through modernization along with loss of plant biodiversity, documentation of this knowledge is crucial for safeguarding and preserving for future generations [28-30].
One of the pioneering studies on ethnobotanical study in home gardens reported only 17 species [22]. The number increased to 78 species after a decade $[27,31]$. This indicates increasing use and importance given by the local community residing in the area. Both of these studies reported that the ethnobotanical plant species cultivated have actually been grown in their home garden and contributing to the conservation of the species for domestic use. Similar studies on home gardens maintaining rich biodiversity of ethnobotanical plants were also reported from Ethiopia [32-36]. This clearly indicates the increase in community consciousness on the conservation values of these ethnobotanical species. The practice also ensures sustainable harnessing of the valuable resource through domestication and leaving the species intact in the wild.

Raising home gardens by local people according to [37] is basically "learning to live with change and uncertainty". The Cooch Behar district has only about $10 \%$ of its total geographical area under forest as compared to about $45 \%$ and $60 \%$ forest cover of the total geographical area in the adjacent districts of Jalpaiguri and Darjeeling, respectively [38]. We therefore expected that the garden owners of Cooch Behar district might be using and conserving the ethnomedicinal plants required for sustaining their primary nutritional care and healthcare by growing and maintaining in their own garden as there is less forest accessible to them or might be distantly located [39-44]. The national government is also now promoting and integrating the use of traditional medicines in the national healthcare through establishing a separate Ministry of Ayush. In spite of all this, the urban population accepts a new wild plant product only after a proper testimony of the specialists [27]. Though home gardens are a very common feature of this region, very limited efforts have been made for the documentation of one of its key characteristics, i.e., ethnomedicinal plants [8-10]. We explored and documented the diversity and population status of ethnomedicinal plants in the home gardens of Cooch Behar along with its associated traditional knowledge and use value. The information and data generated from this study can form a basis for conservation and sustainable utilization of ethnomedicinal plants and also contribute to preserve cultural and genetic diversity.

\section{Materials and methods}

\section{Study area}

The present study was carried in Cooch Behar district of West Bengal, India. The area is located in the Terai region at the northeastern part of West Bengal surrounded by the district of Jalpaiguri and Alipurduar to the north and west (Fig. 1). The area also shares state boundary with Assam to the east and international boundary with 


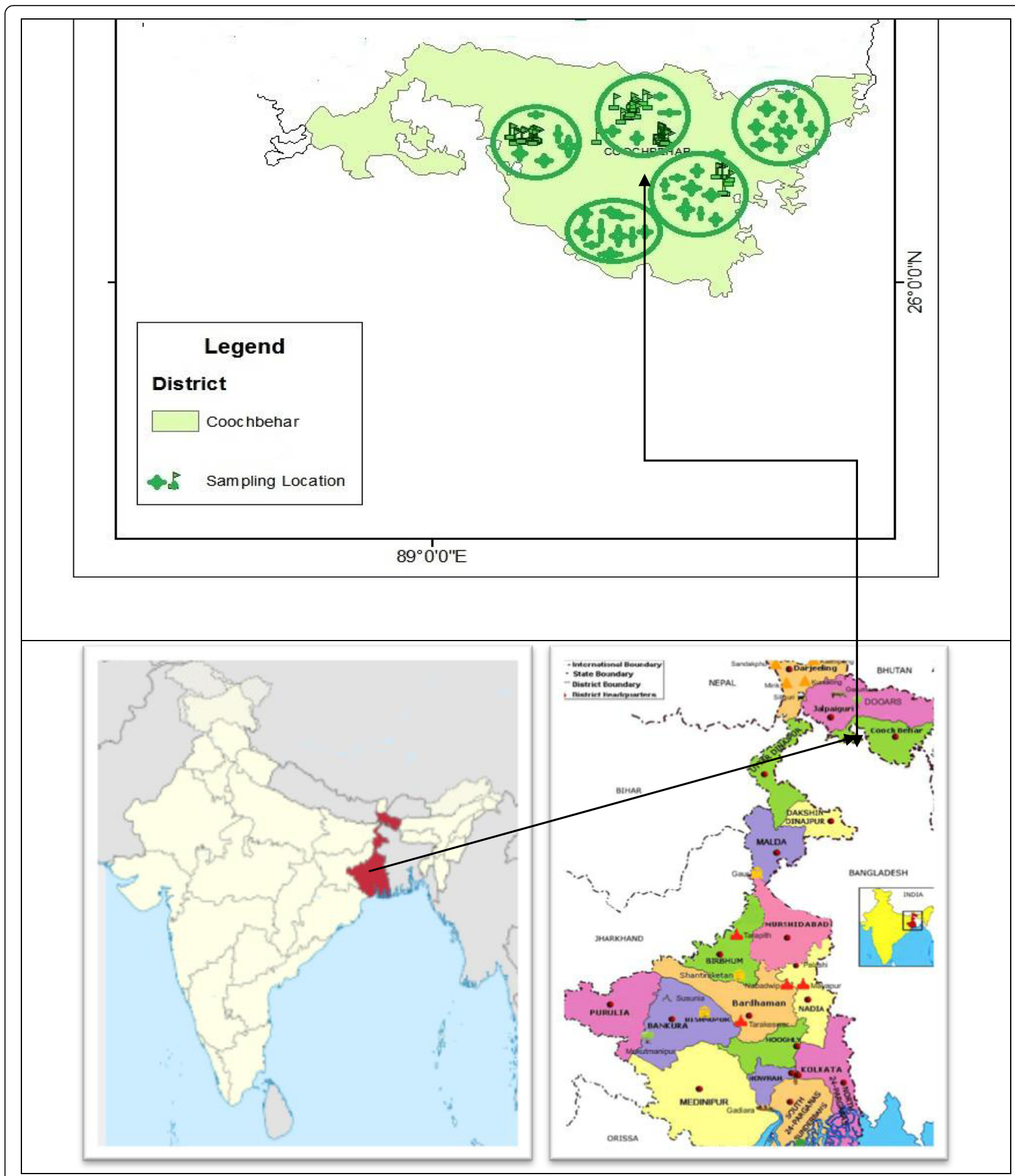

Fig. 1 Map of the study area showing home garden locations

Bangladesh at south, southeast, and southwest. The district is located between $26032^{\prime} 20^{\prime \prime} \mathrm{N}$ to $25057^{\prime} 40^{\prime \prime} \mathrm{N}$ latitude and $89^{\circ} 54^{\prime} 35^{\prime \prime} \mathrm{E}$ to $88^{\circ} 47^{\prime} 40^{\prime \prime} \mathrm{E}$ longitude with an average altitude of $43 \mathrm{msl}$. Cooch Behar is characterized by humid weather and abundant rain. There is a considerable variation in the seasonal and diurnal temperature. In general, July is the hottest month while January is the coldest one. The average minimum and maximum temperature varied from $23.08{ }^{\circ} \mathrm{C}$ during winter (January) to $33.42{ }^{\circ} \mathrm{C}$ during summer (July). On an 
average, the annual rainfall varies from $2000 \mathrm{~mm}$ to $3500 \mathrm{~mm}$; the bulk of which is received during premonsoon and monsoon period (May to September). The quantum of precipitation is very low during winter. The relative humidity of the area varies from 55 to $90 \%$.

The population density of the district is $832 / \mathrm{km}^{2}$ with a total population of 2,819,086 [45]. Majority of them are rural $(89.70 \%)$ including indigenous people with varied socioeconomic conditions. The proportion of landless laborers is very large with $15.18 \%$ males and $4.31 \%$ females $[45,46]$. The communities have their own distinct culture and belief system. The economy of the district is agriculture based, and rice is the major crop with a significant production of jute and other crops. The major occupation of the rural communities is farming. Their subsistence activity in farming includes rearing animals and growing paddy, jute, potato, other green vegetables, and maize in their marginal land holding. The rural population of the district also depends heavily on home gardens for their daily needs especially for day-to-day ailments and dietary and health supplements [10]. Therefore, every household has a home garden around their home with medicinal plants, vegetable, fruit, nuts, timber, and other plants.

\section{Ethnobotanical data collection}

A multidisciplinary approach like collection of plant specimen, interview with structured questionnaire, and focus group discussion (FGD) was conducted for data collection following [47]. The selection of the study sites in the district, i.e., Cooch Behar peri-urban locality, Pundibari, Mathabhanga, Tufanganj I, and Balarampur, was purposive while home gardens were selected randomly. Home gardens are common features of Cooch Behar district due to its humid tropical location, and every household in the district has a home garden with sociocultural and livelihood significance [1, 7-9, 48, 49]. Therefore, Cooch Behar district with its five main locations was selected purposefully. A representative sample of 30 home gardens each from the five villages was selected randomly with a total of 150 home gardens [50,51].

The data were collected from May 2017 to May 2018 through personal interviews using a pretested semi-structured questionnaire containing three sections related to socioeconomic, medicinal plant diversity in home gardens and their use, and therapy [27, 50-52]. Prior to the interview, we tried to establish rapport with the households and pretested the questionnaire for elimination, addition, and alteration with non-sampled households. The society of the study area is patriarchal with husband/father as the head of the household. We generally interviewed the head of the household. However, sometimes the wife, the eldest son, or the daughter of the household was also interviewed when the head of the household was not available [52]. The questions were asked in local language, but the responses were recorded in English. We also conducted ten FGDs, two in each selected area with 20-25 participants which included senior citizens, home garden owners, and local medicine man. Information from these discussions was helpful to interpret our result as this supplemented our household surveys.

\section{Sampling and data analysis Data analysis}

Considering the main objective of our study, we emphasized on documentation of the ethnomedicinal plants from the home gardens. However, floristic structure and composition of these plants were estimated considering the total species and population recorded from the home gardens. The coordinates of each home gardens were recorded by using GPS (Garmin Montana 680). The assessment of medicinal plant diversity and their composition in the home gardens was done by laying down a $10 \times 10 \mathrm{~m}$ quadrat depending upon the area [33]. For the present study, only medicinally important species were taken into consideration based on the consumption and knowledge of the household members. Species identification was not a problem because most of the species grown were need-based and easily identified by the respondent. The plant specimens were collected, systematically tagged, pressed, dried, and mounted on herbarium sheets and were kept under presser for 2 weeks at room temperature. The specimens were poisoned in a solution of mercuric chloride and absolute alcohol ( $2 \mathrm{~g}$ mercuric chloride, dissolved in 1000 $\mathrm{ml}$ absolute alcohol) and mounted on the standard-sized herbarium sheets $\left(11.5 \times 17.5 \mathrm{in}^{2}{ }^{2}\right)$. The data noted in the field notebook during field survey was transferred to the label and pasted on the respective herbarium sheet on the right side at the bottom. The prepared specimens were then cross-checked and identified by a taxonomist of Angiosperms and Biosystematics Research Laboratory, Department of Botany, University of North Bengal and Department of Forestry, Uttar Banga Krishi Viswavidyalaya, West Bengal, India, with proper voucher numbers. For each home garden, the numbers of individuals for each medicinal species were recorded to determine frequency and important value index [53] to get the idea about the distribution and importance of species in these home gardens. Importance value index, a statistical quantity which gives an overall picture of a species and indicates their importance in the plant community, is the sum of relative frequency, relative density, and relative abundance. The frequency was determined by the formula: 


$$
F=\frac{\text { No.of home gardens in which a species occurs }}{\text { Total no.of home gardens }} \times 100
$$

Use value $\left(\mathrm{UV}_{\mathrm{i}}\right)$ of the species was determined using the following formula according to [54],

$$
\mathrm{UVi}=\frac{\sum U i}{N i}
$$

where $U$ is the number of times a species is cited and $N$ is the number of informants. The use value of each species is therefore based objectively on the importance attributed by the informants and does not depend on the opinion of the researcher. The fidelity level (\%) (FL) is measured according to [55] using the formula:

$$
\mathrm{FL} \%=\frac{I_{\mathrm{p}}}{I_{u}} \times 100
$$

where $I_{\mathrm{p}}$ is the number of informants who gave information of a given species as being important, while $I_{\mathrm{u}}$ is the total number of all informants mentioning important medicinal plants

To test the homogeneity of ethnomedicinal knowledge about the medicinal plants, the informant consensus factor $\left(F_{\text {ic }}\right)$ was used [56]. The $F_{\text {ic }}$ for each of the recorded plant species was calculated using the following formula:

$$
F_{\text {ic }}=\frac{N_{\text {ur }}-N_{\mathrm{t}}}{N_{\text {ur }}-1}
$$

where $N_{\text {ur }}$ is the number of use reports for a particular health problem and $N_{\mathrm{t}}$ is the number of species used for a particular health problem by all the informants.

To assess the importance of each species, cultural importance index $(\mathrm{CI})$ was calculated by dividing the number of UR in use-category by the number of informants [57] using the following formula:

$$
\mathrm{CI}_{\mathrm{s}}=\sum_{u=u_{1}}^{u_{\mathrm{NC}}} \sum_{i=i_{1}}^{i_{\mathrm{N}}} \frac{\mathrm{UR}_{\mathrm{ui}}}{N}
$$

where UR is the number of use reports in various health problems (NC) and $N$ is the total number of informants.

\section{Result and discussion}

\section{Socioeconomic status}

All of the 150 surveyed home gardens were having ethnomedicinal plant species ranging from a minimum of 1 to a maximum of 21 species. Among these gardens, $46.66 \%$ of the families were of general caste followed by schedule caste (33.33), other backward class (18\%), and scheduled tribes (2\%). Almost half of the respondents (47.33\%) were having education of higher secondary level followed by high school (31\%) and least (11\%) as illiterate. Majority of the respondents $(90.66 \%)$ were male, and only $9.33 \%$ were female. Most of the respondents (42.66\%) were of the age group of 41-60 followed by $30.66 \%$ of above 61 and $26.66 \%$ for $20-40$ year age group. Most of the home garden owners $(80 \%)$ were having dependency on home gardens for their different resources like ethnomedicine, food-based items, and other ecosystem services (Fig. 2a-f)

\section{Floristic composition}

In the present study, a total of 260 plant species were recorded. Out of them, only 53 were utilized for different ethnobotanical applications (Additional file 1: Table S1). These 53 species belong to 35 families and 45 genera (Table 1). Home gardens had a specific relevance for conservation purposes due to their capacity to represent agro-biodiversity at multiple levels over small spaces and done socially [12, 58, 59]. A total of 281 plant species with 50 medicinal species from home gardens in Tehuacan Valley, Mexico, were reported [60] supporting the pattern of the present study. Documentation of 289 species of plants with 12\% medicinal plants from 106 suburban home gardens in the Thimbirigaskatuwa suburban area, Western Sri Lanka, also supports the results of the present study [61]. Ethnomedicinal richness of 47 species has also been reported from home gardens of Pachmarhi Biosphere Reserve, India [62]. The reported results of [61, 62] also support to the contribution of ethnomedicinal plant species with total plant diversity from the home gardens. The earlier report of only 13 species of medicinal plants from the home gardens of North Bengal is very less as compared to the 53 species in the present study [63]. The variation may be due to the fact that the study conducted by [63] was restricted to 40 home gardens from the district of Cooch Behar. High diversity of species with an immediate use in the home is the most prominent feature of home gardens [64].

The contribution to 53 species was dominated by woody perennials (37.73\%) followed by herb $(28.30 \%)$, shrub 12 (22.64\%), and climber 6 (11.32\%), respectively (Table 2). The predominance of woody trees as a common rule in home gardens in the present study is well supported by the results of [65-68]. The contribution of fruit species is crucial for the diet of household members in terms of vitamins and fibers [69-72]. The dominance of woody trees in the present study is in contrast with the findings of [73] who found low numbers of trees in each garden, mostly because of their greater demand for space in Central Italy.

Lamiaceae was the dominant family with five genera and six species followed by Acanthaceae with three genera and four species, Euphorbiaceae with three genera and three species, and Combretaceae with one genera and three species. The highest number of individuals (160) was reported for Cocus nucifera followed by Hibiscus rosa-sinensis (143) (Table 1). Ocimum sanctum was the most frequent species followed by Cynodon dactylon (87.33\%), Piper betal (85.33\%), Hibiscus rosa-sinensis (80.67\%), and Zingiber officinale (74.00\%). 


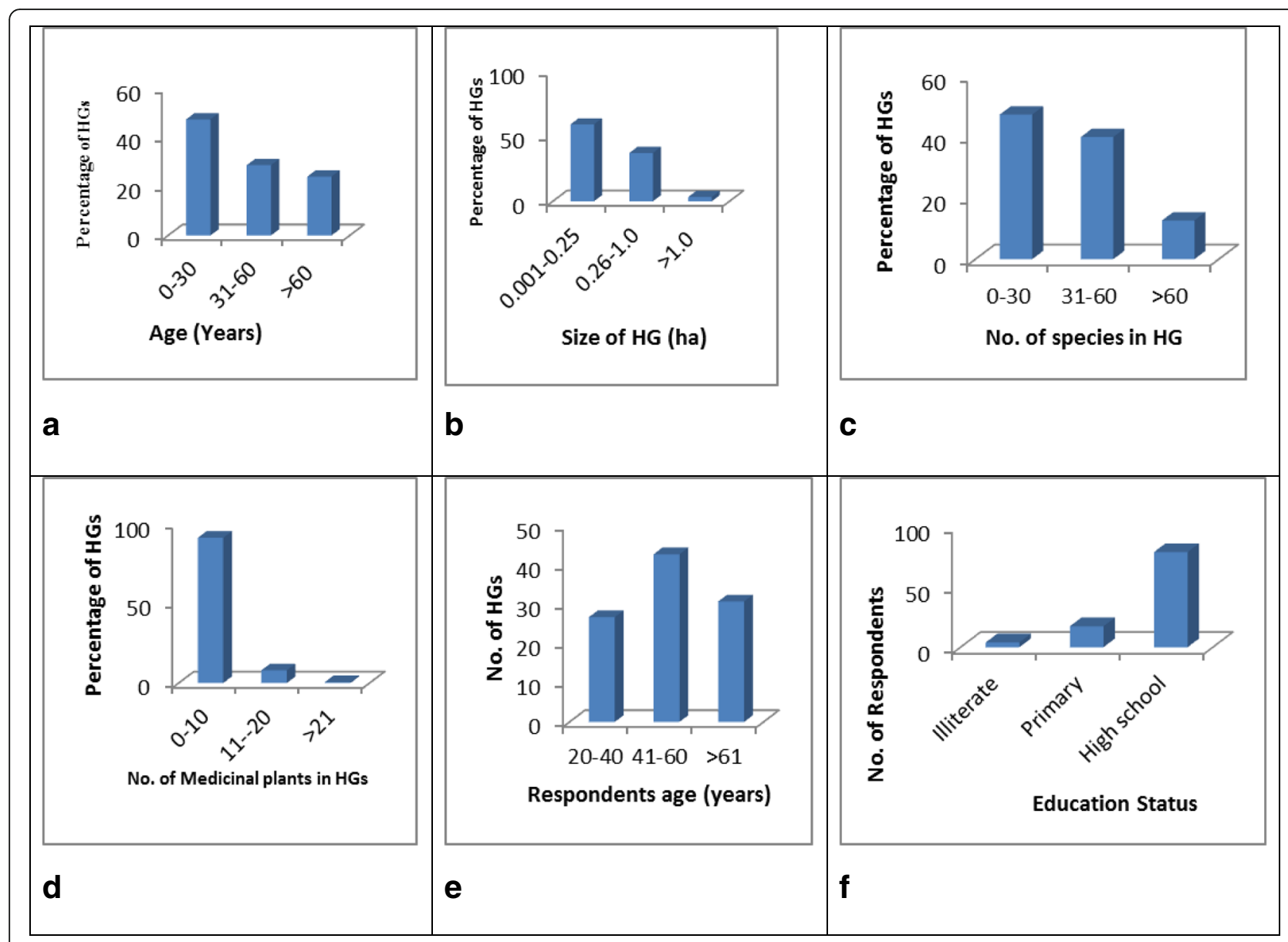

Fig. 2 Basic information on home gardens collated from the study area. a Range of age of the home garden (HG) in years. b Range of size of the homestead garden in hectares. c Range of number of species. $\mathbf{d}$ Range of number of medicinal plants. e Age of the respondents in years. $\mathbf{f}$ Educational status of the home garden owners

The least frequent species recorded was Terminalia bellirica. The highest frequency (\%) was observed in Ocimum sanctum because this species is commonly used for cold and cough and taken with hot water instead of tea everyday morning. The high individual occurrence of Cocus nucifera in these home agroforestry gardens is due to the economic viability and home consumption. The important value index (IVI) is used to determine the overall importance of each species in the community structure. The recorded average value of IVI was 5.68 with range of 2.05 to 11.06 (Table 1). The highest value of IVI (11.06) was recorded for Cocus nucifera and lowest (2.05) for Terminalia bellrica. The dominance of Cocus nucifera in home gardens of North Bengal was also reported by [1].

\section{Parts used and ailments treated}

The present study reported the leaf of 19 species as dominant plant part used as medicinal part followed by fruit (12), bark (9), root (7), and whole plant (4) (Fig. 3;
Table 2). Leaves of the ethnomedicinal plants as dominant plant part to treat different diseases have also been reported by several studies [24, 25, 27, 73]. Fruit was also reported as dominant and widely used part for traditional medicines [23, 74]. These can further lead to a scientific assessment of the traditional medicines used, which may provide a lead in drug development $[75,76]$. Botanically derived medicinal plants played a major role in human societies throughout history and prehistory $[19,20]$. Traditional medicinal use of plants is strongly related to physiological and pharmacological activity of active plant ingredients [67]. The plant parts utilized were either taken in the form of juice, paste, decoction, powder, infusion, and chewing raw plant parts. These utilized plant parts are used to cure 20 ailments prevailing among the dependent households (Table 2). The maximum species (10) were documented for the treatment of stomach disorders followed by cough and cold (6), wounds, and jaundice of four species (Fig. 4; Table 2). 
Table 1 Scientific name of documented species, families, ecological status, and other indices

\begin{tabular}{|c|c|c|c|c|c|c|c|c|}
\hline Botanical name/accession number & Family & Local name & $\mathrm{NI}$ & $\mathrm{F}(\%)$ & $\mid \mathrm{VI}$ & UV & $\mathrm{FL}(\%)$ & $\mathrm{Cl}$ \\
\hline Andrographis paniculata (Burm. f.) Wall. (10061) & Acanthaceae & Kalo meg/kal meg & 16 & 10.67 & 2.66 & 0.093 & 93.75 & 0.048 \\
\hline $\begin{array}{l}\text { Hygrophila schulli (Ham.) M.R. and S.M. } \\
\text { Almeida Almeida } \\
(10068)^{a}\end{array}$ & Acanthaceae & Kulekhara & 49 & 32.67 & 4.88 & 0.073 & 22.45 & 0.033 \\
\hline $\begin{array}{l}\text { Justicia adhatoda L. } \\
\text { (UBKV FOR 328) }\end{array}$ & Acanthaceae & Basakpata & 40 & 33.33 & 4.31 & 0.140 & 42.00 & 0.111 \\
\hline $\begin{array}{l}\text { Justicia gendarussa Burm.f. } \\
\text { (UBKV FOR 329) }\end{array}$ & Acanthaceae & Bishalyokoroni & 72 & 29.33 & 6.43 & 0.107 & 36.36 & 0.071 \\
\hline $\begin{array}{l}\text { Acorus calamus L. } \\
(\text { UBKV FOR 252) }\end{array}$ & Acoraceae & Bogh & 34 & 22.67 & 3.87 & 0.027 & 11.76 & 0.024 \\
\hline Lannea coromandelica (Houtt.) Merr. & Anarcardiaceae & Jiga & 87 & 58.00 & 7.43 & 0.013 & 4.60 & 0.056 \\
\hline $\begin{array}{l}\text { Centella asiatica (L.) Urban } \\
(10097)^{\mathrm{a}}\end{array}$ & Apiaceae & Thankuni & 89 & 59.33 & 7.56 & 0.467 & 78.65 & 0.091 \\
\hline $\begin{array}{l}\text { Alstonia scholaris (L.) R. Br. } \\
(10089)^{\mathrm{a}}\end{array}$ & Apocynaceae & Chatim & 44 & 22.67 & 4.65 & 0.033 & 23.53 & 0.167 \\
\hline $\begin{array}{l}\text { Rauvolfia serpentinea (L.) Benth. } \\
\text { ex Kurz. (UBKV FOR 271) }\end{array}$ & Apocynaceae & Sarpaganda & 72 & 29.33 & 6.43 & 0.040 & 13.64 & 0.143 \\
\hline $\begin{array}{l}\text { Cocus nucifera } \mathrm{L} \text {. } \\
\text { (UBKV FOR 309) }^{\mathrm{b}}\end{array}$ & Arecaceae & Narkel & 160 & 51.33 & 11.06 & 0.067 & 12.99 & 0.091 \\
\hline $\begin{array}{l}\text { Asparagus racemosus Willd. } \\
\text { (UBKV FOR 255) }\end{array}$ & Asparagaceae & Shatamuli & 19 & 11.33 & 2.98 & 0.020 & 25.00 & 0.029 \\
\hline $\begin{array}{l}\text { Ageratum conyzoides (L.) L. } \\
(\text { UBKV FOR 29) }\end{array}$ & Asteraceae & Gandhe & 17 & 10.67 & 2.79 & 0.080 & 12.50 & 0.063 \\
\hline $\begin{array}{l}\text { Oroxylum indicum (L.) Kurz } \\
(10111)^{\mathrm{a}}\end{array}$ & Bignoniaceae & Surimala & 29 & 15.33 & 3.73 & 0.080 & 52.17 & 0.037 \\
\hline $\begin{array}{l}\text { Ananas comosus (L) Merr. } \\
(\text { UBKV FOR 282) }\end{array}$ & Bromeliaceae & Anaras & 109 & 46.67 & 8.39 & 0.020 & 4.29 & 0.077 \\
\hline $\begin{array}{l}\text { Carica papaya L. } \\
\text { (UBKV FOR 298) }^{b}\end{array}$ & Caricaceae & Paypay & 88 & 36.00 & 7.27 & 0.027 & 7.41 & 0.200 \\
\hline $\begin{array}{l}\text { Terminalia arjuna (Roxb. ex Dc.) } \\
\text { Wight and Arn. }(10,087)^{\mathrm{a}}\end{array}$ & Combretaceae & Arjun & 21 & 8.67 & 3.69 & 0.073 & 84.62 & 0.031 \\
\hline 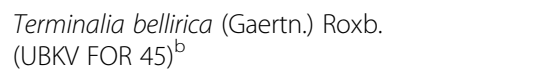 & Combretaceae & Bahera & 7 & 4.67 & 2.06 & 0.047 & 22.22 & 0.036 \\
\hline $\begin{array}{l}\text { Terminalia chebula Retz. } \\
(10124)^{\mathrm{a}}\end{array}$ & Combretaceae & Haritaki & 25 & 16.00 & 3.30 & 0.107 & 66.67 & 0.063 \\
\hline $\begin{array}{l}\text { Cuscuta europaea L. } \\
(10121)^{\mathrm{a}}\end{array}$ & Convolvulaceae & Sarnolata & 28 & 18.67 & 3.47 & 0.040 & 46.43 & 0.077 \\
\hline $\begin{array}{l}\text { Bryophyllum pinnatum (Lam.) Oken } \\
(10091)^{\mathrm{a}}\end{array}$ & Crassulaceae & Patharkuchi & 74 & 46.67 & 6.50 & 0.280 & 45.71 & 0.200 \\
\hline $\begin{array}{l}\text { Equisetum arvense L. } \\
(10159)^{\mathrm{a}}\end{array}$ & Equisetaceae & Harvanga & 17 & 7.33 & 3.38 & 0.033 & 18.18 & 0.031 \\
\hline $\begin{array}{l}\text { Phyllanthus emblica L. } \\
\text { (UBKV FOR 263) }\end{array}$ & Euphorbiaceae & Amloki & 50 & 21.33 & 5.19 & 0.033 & 86.67 & 0.125 \\
\hline $\begin{array}{l}\text { Jatropha curcas L. } \\
\text { (UBKV FOR 264) }^{\mathrm{b}}\end{array}$ & Euphorbiaceae & Bharenda & 44 & 24.00 & 4.61 & 0.080 & 33.33 & 0.037 \\
\hline $\begin{array}{l}\text { Euphorbia hirta L. } \\
(10079)^{\mathrm{a}}\end{array}$ & Euphorbiaceae & Lal dudhi & 71 & 47.33 & 6.35 & 0.020 & 5.63 & 0.167 \\
\hline $\begin{array}{l}\text { Clerodendrum infortunatum L. } \\
(10070)^{\mathrm{a}}\end{array}$ & Lamiaceae & Vati & 85 & 56.00 & 7.28 & 0.107 & 19.05 & 0.048 \\
\hline Mentha arvensis L. & Lamiaceae & Pudina & 76 & 50.67 & 6.69 & 0.113 & 22.37 & 0.056 \\
\hline Ocimum gratissimum L. & Lamiaceae & Ram tulsi & 19 & 12.67 & 2.86 & 0.027 & 21.05 & 0.031 \\
\hline Ocimum sanctum L. & Lamiaceae & Tulsi & 135 & 90.00 & 10.65 & 0.533 & 89.63 & 0.077 \\
\hline
\end{tabular}


Table 1 Scientific name of documented species, families, ecological status, and other indices (Continued)

\begin{tabular}{|c|c|c|c|c|c|c|c|c|}
\hline Botanical name/accession number & Family & Local name & $\mathrm{Nl}$ & $F(\%)$ & $\mathrm{IVI}$ & UV & FL (\%) & $\mathrm{Cl}$ \\
\hline $\begin{array}{l}\text { Leucas aspera (Willd.) Link. } \\
\text { (UBKV FOR 331) }\end{array}$ & Lamiaceae & Kanchisa & 101 & 67.33 & 8.37 & 0.067 & 6.93 & 0.333 \\
\hline $\begin{array}{l}\text { Vitex negundo L. } \\
(10069)^{\mathrm{a}}\end{array}$ & Lamiaceae & Nishinda & 29 & 18.67 & 3.55 & 0.040 & 21.43 & 0.047 \\
\hline $\begin{array}{l}\text { Cinnamomum tamala (Buch.-Ham.) } \\
\text { T.Nees and Eberm. }\end{array}$ & Lauraceae & Tezpata & 31 & 19.33 & 3.71 & 0.020 & 10.34 & 0.077 \\
\hline Cinnamomum verum J.Presl & Lauraceae & Dalchini & 17 & 4.67 & 4.64 & 0.013 & 28.57 & 0.024 \\
\hline $\begin{array}{l}\text { Punica granatum L. } \\
(\text { (UBKV FOR } 345)^{b}\end{array}$ & Lythraceae & Dhalim & 43 & 20.67 & 4.66 & 0.020 & 9.68 & 0.130 \\
\hline $\begin{array}{l}\text { Abroma augusta (L.) L.f. } \\
(10104)^{\mathrm{a}}\end{array}$ & Malvaceae & Allot kamal/ulatkambal & 72 & 29.33 & 6.43 & 0.107 & 36.36 & 0.116 \\
\hline 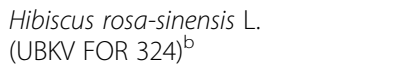 & Malvaceae & Jawa phul & 143 & 80.67 & 10.68 & 0.027 & 33.16 & 0.029 \\
\hline $\begin{array}{l}\text { Azadirachta indica A.Juss } \\
\text { (UBKV FOR 256) }^{\mathrm{b}}\end{array}$ & Meliaceae & Neem & 31 & 16.00 & 3.88 & 0.147 & 87.50 & 0.063 \\
\hline $\begin{array}{l}\text { Tinospora sinensis (Lour.) Merr. } \\
(10137)^{a}\end{array}$ & Menispermaceae & Gulancha & 14 & 9.33 & 2.53 & 0.040 & 14.29 & 0.167 \\
\hline $\begin{array}{l}\text { Mimosa pudica L. } \\
\text { (UBKV FOR 93) }^{\mathrm{b}}\end{array}$ & Mimosaceae & Lajjawati & 58 & 38.67 & 5.48 & 0.093 & 5.17 & 0.094 \\
\hline $\begin{array}{l}\text { Streblus asper Lour. } \\
(10084)^{a}\end{array}$ & Moraceae & Shaora & 61 & 24.67 & 5.85 & 0.053 & 2.70 & 0.059 \\
\hline $\begin{array}{l}\text { Moringa oleifera Lam. } \\
(\text { (UBKV FOR 336) })^{\mathrm{b}}\end{array}$ & Moringaceae & Sajana & 23 & 12.00 & 3.39 & 0.053 & 16.67 & 0.067 \\
\hline $\begin{array}{l}\text { Averrhoa carambola L. } \\
(10056)^{\mathrm{a}}\end{array}$ & Oxalidaceae & Kamranga & 24 & 14.67 & 3.27 & 0.120 & 9.09 & 0.043 \\
\hline $\begin{array}{l}\text { Piper betle L. } \\
(10120)^{\mathrm{a}}\end{array}$ & Piperaceae & Pan & 128 & 85.33 & 10.18 & 0.280 & 32.81 & 0.167 \\
\hline $\begin{array}{l}\text { Piper nigrum L. } \\
(\text { UBKV FOR 268) }\end{array}$ & Piperaceae & Golmarich & 96 & 64.00 & 8.03 & 0.067 & 10.42 & 0.071 \\
\hline $\begin{array}{l}\text { Cynodon dactylon (L.) Pers. } \\
(\text { UBKV FOR 261) }\end{array}$ & Poaceae & Dubbaghass & 136 & 87.33 & 10.60 & 0.240 & 26.09 & 0.070 \\
\hline $\begin{array}{l}\text { Ziziphus mauritiana Lam. } \\
(10122)^{a}\end{array}$ & Rhamnaceae & Kul & 79 & 52.67 & 6.89 & 0.020 & 43.04 & 0.333 \\
\hline $\begin{array}{l}\text { Aegle marmelos (L.) Correa } \\
(10062)^{\mathrm{a}}\end{array}$ & Rutaceae & Bael & 40 & 20.00 & 4.44 & 0.093 & 46.67 & 0.154 \\
\hline $\begin{array}{l}\text { Murraya koenigii (L.) Spreng. } \\
(10063)^{\mathrm{a}}\end{array}$ & Rutaceae & Curry pata & 85 & 51.33 & 7.17 & 0.020 & 3.90 & 0.095 \\
\hline Bacopa monnieri (L.) Wettest & Scrophulariaceae & Brahmi & 32 & 21.33 & 3.73 & 0.033 & 15.63 & 0.095 \\
\hline $\begin{array}{l}\text { Datura metel L. } \\
(\text { UBKV FOR 262) }\end{array}$ & Solanaceae & Dhatura & 52 & 34.67 & 5.08 & 0.153 & 44.23 & 0.108 \\
\hline $\begin{array}{l}\text { Aloe vera (L.) Burm. f. } \\
(\text { (UBKV FOR 279) }\end{array}$ & Xanthorrhoeaceae & Aloe vera & 77 & 50.00 & 6.73 & 0.207 & 70.67 & 0.167 \\
\hline Curcuma aeruginosa Roxb. & Zingiberaceae & Jhanglihalud & 28 & 18.67 & 3.47 & 0.033 & 14.29 & 0.273 \\
\hline $\begin{array}{l}\text { Curcuma longa L. } \\
(10081)^{\mathrm{a}}\end{array}$ & Zingiberaceae & Halud & 108 & 72.00 & 8.84 & 0.247 & 34.26 & 0.077 \\
\hline $\begin{array}{l}\text { Zingiber officinale Roscoe. } \\
(10082)^{\mathrm{a}}\end{array}$ & Zingiberaceae & Ada & 111 & 74.00 & 9.04 & 0.187 & 25.23 & 0.333 \\
\hline
\end{tabular}

$N I$ number of individuals, $F$ frequency, $I V I$ importance value index, UV use value, $F L$ fidelity, $C l$ cultural importance

${ }^{a}$ Species identified from Taxonomy of Angiosperms and Biosystematics Research Laboratory, Department of Botany, University of North Bengal

${ }^{b}$ Species identified from herbarium of Department of Forestry, UBKV

The stomach disease is prevailing in the region among all age groups due to iron rich water. The use of Aegle marmelos in stomach disorder in the present study has been supported by the findings of $[77,78]$ who reported it for digestive disorders. Azadirachta indica used in fever in the present study is also reported for the same 
Table 2 Ethnomedicinal plant species with their uses and application procedure

\begin{tabular}{|c|c|c|c|c|c|}
\hline Botanical name & Plant form & Used for & Parts used & Procedure & Reported cases \\
\hline$\overline{\text { Abroma augusta (L.) L. f. }}$ & Shrub & Urine problem & $\begin{array}{l}\text { New buds, } \\
\text { leaf, and root }\end{array}$ & $\begin{array}{l}\text { Juice of fresh leaves along with honey is } \\
\text { given orally as expectorant. Juice of leaf } \\
\text { is inhaled for bleeding nose (sinusitis). } \\
\text { Dried powder of entire plant parts is } \\
\text { given for bronchitis and cough. }\end{array}$ & $\begin{array}{l}\text { Night wetting, jaundice, stomach } \\
\text { disorder [23], blood dysentery, diarrhea } \\
\text { [83], menstrual disorder }[100,101]\end{array}$ \\
\hline Acorus calamus L. & Herb & $\begin{array}{l}\text { Fever and stomach } \\
\text { disorders }\end{array}$ & Leaf, root & $\begin{array}{l}\text { Juice of root is given orally in stomach } \\
\text { disorders, bronchitis, and fever, and its } \\
\text { small piece is chewed to clear the } \\
\text { throat. }\end{array}$ & $\begin{array}{l}\text { Joint pain, evil spirit [27], for removing } \\
\text { animal lice [102] }\end{array}$ \\
\hline $\begin{array}{l}\text { Aegle marmelos } \\
\text { (L.) Correa }\end{array}$ & Tree & Stomach problem & Fruit & $\begin{array}{l}\text { Fruit and seed is used to treat } \\
\text { stomach problem. }\end{array}$ & $\begin{array}{l}\text { Stomach disorder, appetizer, dysentery } \\
{[27,103]}\end{array}$ \\
\hline $\begin{array}{l}\text { Ageratum conyzoides } \\
\text { (L.) L. }\end{array}$ & Climber & Wounds & Leaf & $\begin{array}{l}\text { Leaf juice is given to cure bleeding from } \\
\text { cuts and wounds. Plant paste is applied } \\
\text { to cure muddy wounds between toes } \\
\text { during rainy season. }\end{array}$ & Cuts and wounds $[27,103]$ \\
\hline Aloe vera $(\mathrm{L}$.$) Correa$ & Herb & Skin problem & Leaves & $\begin{array}{l}\text { Leaf pulp is applied on skin burns } \\
\text { and other problems. }\end{array}$ & $\begin{array}{l}\text { For burnt skin, stomach disorder, body } \\
\text { pain, diabeties, general health issues, } \\
\text { cold, and cough }[27,81,103]\end{array}$ \\
\hline $\begin{array}{l}\text { Alstonia scholaris (L.) } \\
\text { R. Br. }\end{array}$ & Tree & Cure skin problems & Bark & $\begin{array}{l}\text { Bark paste is smeared of the } \\
\text { infected part of the body. }\end{array}$ & $\begin{array}{l}\text { Cold and cough, against stomach } \\
\text { worms, lactation, snake bite, for ulcers, } \\
\text { sores, and tumors }[26,27,90,103,104]\end{array}$ \\
\hline $\begin{array}{l}\text { Ananas comosus (L) } \\
\text { Kurz }\end{array}$ & Herb & Kill stomach worms & Leaf & Leaf extract is used to kill worms. & $\begin{array}{l}\text { For stomach worms, against scurvy } \\
{[24,26,27,103]}\end{array}$ \\
\hline $\begin{array}{l}\text { Andrographis paniculata } \\
\text { (Brum.f.) Wall. ex Nees }\end{array}$ & Herb & Liver & Whole plant & $\begin{array}{l}\text { Whole plant or leaf juice extract is used } \\
\text { to cure liver problems. }\end{array}$ & $\begin{array}{l}\text { Diabetes, liver problem, fever, cough } \\
\text { and cold, stomach pain, Malaria [27, } 90, \\
103,104]\end{array}$ \\
\hline $\begin{array}{l}\text { Asparagus racemosus } \\
\text { Willd. }\end{array}$ & Herb & $\begin{array}{l}\text { Diabetes and } \\
\text { dysentery }\end{array}$ & Tuber & $\begin{array}{l}\text { Fleshy root is dried, and its powder is } \\
\text { consumed with water to treat diabetes } \\
\text { and dysentery }\end{array}$ & $\begin{array}{l}\text { Cuts and wounds, urine disorder, } \\
\text { swelling, diabetes, dysentery, stomach } \\
\text { disorders, improving memory } \\
{[22,27,100,101,103]}\end{array}$ \\
\hline Averrhoa carambola L. & Tree & $\begin{array}{l}\text { Jaundice and } \\
\text { dysentery }\end{array}$ & Fruit & $\begin{array}{l}\text { Fresh fruit is eaten to treat jaundice, } \\
\text { and dry fruit is used to treat dysentery. }\end{array}$ & Jaundice and liver problem $[27,103]$ \\
\hline $\begin{array}{l}\text { Azadirachta indica } \\
\text { A. Juss }\end{array}$ & Tree & $\begin{array}{l}\text { Fever and } \\
\text { skin rashes }\end{array}$ & Leaf & $\begin{array}{l}\text { Leaf sap is used to treat fever and } \\
\text { acidity, and leaf is boiled with water } \\
\text { and used as a bath water to treat } \\
\text { skin rashes. }\end{array}$ & $\begin{array}{l}\text { Allergy, pneumonia, appetite, stomach } \\
\text { disorder, skin disorder, intestinal worms, } \\
\text { eye problems, malarial fever, blood } \\
\text { purification }[26,27,100,103,105]\end{array}$ \\
\hline $\begin{array}{l}\text { Bacopa monnieri (L.) } \\
\text { Wettest }\end{array}$ & Herb & Indigestion & Whole plant & $\begin{array}{l}\text { Boiled tender leaf is used } \\
\text { for indigestion. }\end{array}$ & \\
\hline $\begin{array}{l}\text { Bryophyllum pinnatum } \\
\text { (Lam.) Oken }\end{array}$ & Herb & Stomach stone & Leaf & $\begin{array}{l}\text { Leaves in soaked water are used and } \\
\text { drunk raw to treat stomach stone. }\end{array}$ & $\begin{array}{l}\text { Cuts and wounds, for burnt skin, for gall } \\
\text { bladder stone, piles, stomach problems } \\
{[27,84,103]}\end{array}$ \\
\hline Carica papaya L. & Tree & Jaundice & Fruit & $\begin{array}{l}\text { Ripen fruit is consumed to treat } \\
\text { against jaundice }\end{array}$ & $\begin{array}{l}\text { Gastroenteritis, appetizer, digestion, } \\
\text { cough, dysentery } \\
{[23,24,27,100,101,103]}\end{array}$ \\
\hline $\begin{array}{l}\text { Centella asiatica } \\
\text { (L.) Urb. }\end{array}$ & Herb & Diarrhea/dysentery & Leaf & $\begin{array}{l}\text { Leaf paste juice is taken orally } \\
\text { for diarrhea/dysentery. }\end{array}$ & $\begin{array}{l}\text { Jaundice, typhoid, dysentery, pain, } \\
\text { constipation, indigestion, dog bite, } \\
\text { appetizer }[22,27,100,101,103]\end{array}$ \\
\hline $\begin{array}{l}\text { Cinnamomum tamala } \\
\text { (Buch.-Ham) } \\
\text { T. Nees \& Eberm. }\end{array}$ & Tree & $\begin{array}{l}\text { Hypertension } \\
\text { and diarrhea }\end{array}$ & $\begin{array}{l}\text { Leaf and } \\
\text { bark }\end{array}$ & Leaf and bark are consumed. & \\
\hline $\begin{array}{l}\text { Cinnamomum } \\
\text { verum J.Presl }\end{array}$ & Tree & $\begin{array}{l}\text { Gastrointestinal } \\
\text { problems and } \\
\text { diabetes }\end{array}$ & $\begin{array}{l}\text { Bark and } \\
\text { leaves }\end{array}$ & $\begin{array}{l}\text { Raw small piece of bark is chewed to } \\
\text { treat gastrointestinal problems and } \\
\text { diabetes. }\end{array}$ & \\
\hline $\begin{array}{l}\text { Clerodendrum } \\
\text { infortunatum } \mathrm{L} .\end{array}$ & Herb & Stomach worm & Young buds & Paste of young shoot is taken orally. & \\
\hline Cocus nucifera L. & Tree & $\begin{array}{l}\text { Stomach problems } \\
\text { and weight loss }\end{array}$ & Fruit water & $\begin{array}{l}\text { Water present in coconut fruit is used } \\
\text { in curing stomach problem and } \\
\text { weight loss. }\end{array}$ & $\begin{array}{l}\text { Weight loss, hair vitalizer, } \\
\text { chicken pox scar [27, 76, 103] }\end{array}$ \\
\hline $\begin{array}{l}\text { Curcuma aeruginosa } \\
\text { Roxb. }\end{array}$ & Herb & Inflammation & Rhizome & $\begin{array}{l}\text { Fresh rhizome paste is used } \\
\text { against inflammation. }\end{array}$ & \\
\hline
\end{tabular}


Table 2 Ethnomedicinal plant species with their uses and application procedure (Continued)

\begin{tabular}{|c|c|c|c|c|c|}
\hline Botanical name & Plant form & Used for & Parts used & Procedure & Reported cases \\
\hline Curcuma longa $L$. & Herb & Antiseptic & Rhizome & $\begin{array}{l}\text { Rhizome paste is applied as antiseptic. } \\
\text { Rhizome and salt are taken to treat } \\
\text { cough and cold. }\end{array}$ & $\begin{array}{l}\text { Cuts and wounds, stomach disorder, } \\
\text { lactation of animals, cough and cold, } \\
\text { fever, bone fracture, blood purifier, } \\
\text { snake bite }[22,27,100,103]\end{array}$ \\
\hline Cuscuta europaea L. & Climber & $\begin{array}{l}\text { Jaundice or } \\
\text { liver problem }\end{array}$ & Whole plant & $\begin{array}{l}\text { Whole plant juice is used to } \\
\text { treat jaundice. }\end{array}$ & Jaundice $[27,103]$ \\
\hline $\begin{array}{l}\text { Cynodon dactylon } \\
\text { (L.) Pers. }\end{array}$ & Herb & Cut/wounds & Leaf & $\begin{array}{l}\text { Young crush leaf paste is used to apply } \\
\text { on cut wounds }\end{array}$ & $\begin{array}{l}\text { Cuts and wounds, bleeding, vomiting, } \\
\text { indigestion, piles, asthma } \\
{[22-24,27,100,101,103]}\end{array}$ \\
\hline Datura metel L. & Herb & Pain reliever & $\begin{array}{l}\text { Leaf, flower } \\
\text { and fruit }\end{array}$ & $\begin{array}{l}\text { Few dried or fresh seeds are taken } \\
\text { as pain reliever. }\end{array}$ & $\begin{array}{l}\text { Cuts and wounds, diarrhea, tooth pain, } \\
\text { asthmatic, cold and cough, anti-rabies } \\
{[22,37,100,101,103]}\end{array}$ \\
\hline Equisetum arvense L. & Herb & Bone disease & Whole plant & $\begin{array}{l}\text { Paste of leaf and root are applied on } \\
\text { fracture directly to reduce bone disease. }\end{array}$ & \\
\hline Euphorbia hirta L. & Herb & Piles & Whole plant & $\begin{array}{l}\text { Tender plant parts are crushed and } \\
\text { consumed daily with milk to get } \\
\text { relief against piles. }\end{array}$ & \\
\hline Hibiscus rosa-sinensis L. & Shrub & $\begin{array}{l}\text { Burning sensation, } \\
\text { fatigue, skin } \\
\text { diseases, and } \\
\text { blood dysentery }\end{array}$ & $\begin{array}{l}\text { Root, } \\
\text { flower buds }\end{array}$ & $\begin{array}{l}\text { Root extract is used to treat cough and } \\
\text { fever. Flower bud is used to treat blood } \\
\text { dysentery. Leaf paste is used to treat } \\
\text { burning sensation, fatigue, and skin } \\
\text { diseases. }\end{array}$ & $\begin{array}{l}\text { Tonsillitis, dandruff, hair loss, burning } \\
\text { sensation, fatigue, fever }[25,27,103]\end{array}$ \\
\hline $\begin{array}{l}\text { Hygrophila schulli } \\
\text { (Hamilt.) M.R. \& S.M. } \\
\text { Almeida }\end{array}$ & Herb & Anemia & $\begin{array}{l}\text { Leaf, tender } \\
\text { stem }\end{array}$ & $\begin{array}{l}\text { Leaves and young stems are boiled } \\
\text { and taken daily to cure anemia. }\end{array}$ & \\
\hline Jatropha curcas L. & Shrub & Tooth ache & Branch & $\begin{array}{l}\text { Young branch is used as tooth brush } \\
\text { to reduce pain. }\end{array}$ & $\begin{array}{l}\text { Diarrhea, headache, cuts and wounds, } \\
\text { digestion, gum problems } \\
{[22,27,83,84,103]}\end{array}$ \\
\hline Justicia Adhatoda L. & Herb & $\begin{array}{l}\text { Bronchitis, cold, } \\
\text { and cough }\end{array}$ & Leaf & $\begin{array}{l}\text { Leaf juice is used to treat chronic } \\
\text { bronchitis, cough, and cold. }\end{array}$ & $\begin{array}{l}\text { Cough and cold, paralysis, allergy, cuts } \\
\text { and wounds, piles, leprosy and diabetes, } \\
\text { chronic bronchitis }[25,27,86,103]\end{array}$ \\
\hline $\begin{array}{l}\text { Justicia gendarussa } \\
\text { Burm.f. }\end{array}$ & Herb & $\begin{array}{l}\text { Headache, cut, } \\
\text { and wounds }\end{array}$ & Leaf & $\begin{array}{l}\text { Crushed leaves are placed on cuts with } \\
\text { the extract for healing. It is applied on } \\
\text { forehead for treating headache. }\end{array}$ & $\begin{array}{l}\text { Cancer, antiseptic, headache, } \\
\text { cuts and wounds }[27,103]\end{array}$ \\
\hline $\begin{array}{l}\text { Lannea coromandelica } \\
\text { (Houtt.) Merr. }\end{array}$ & Tree & Piles and wounds & Gum & $\begin{array}{l}\text { Gum is applied directly on piles and } \\
\text { wounds. }\end{array}$ & \\
\hline
\end{tabular}

\begin{tabular}{|c|c|c|}
\hline $\begin{array}{l}\text { Leucas aspera } \\
\text { (Willd.) Link. }\end{array}$ & Herb & $\begin{array}{l}\text { Stomach disorder, } \\
\text { swelling, and stop } \\
\text { bleeding }\end{array}$ \\
\hline
\end{tabular}

Mentha arvensis L. Herb Flatulence, diarrhea, Leaves and nausea

Leaf juice is used to cure stomach disorder; hand-crushed leaves are inhaled to cure headache; leaf paste is applied to stop cut bleeding.

Stomach disorder, swelling, headache, body pain, cuts and wounds, tooth pain bleeding $[27,103]$

Bruised leaves are applied to get relief from headache, and leaf extract juice is administered orally against vomiting, nausea, flatulence, and diarrhea.

Mimosa pudica L. Herb

Moringa oleifera Lam. Tree

$\begin{aligned} & \text { Murraya koenigii } \\ & \text { (L.) Spreng. }\end{aligned}$
Ocimum gratissimum L. Herb

Fever and diarrhea

Fever, cough and cold, headache, nausea, diarrhea, dysentery, and skin diseases

Ocimum sanctum L. Herb gastroenteritis
Leaf and bark

Blood pressure and Leaf and fruits

Decotation of leaf and bark is used to control orchitis and used as depurative.

Tender leaf juice and cooked fruits are taken to balance blood pressure.

Leaf, bark, Leaf juice is consumed to control and root black fever and diarrhea.

Leaves,

flower

Decoction of plant is given to treat fever, cough, cold, headache, nausea, diarrhea, dysentery, and skin diseases.

Leaves are used to treat cough and cold.
Cough and cold, neck pain, cancer, gastroenteritis, asthma, urinary disorder $[22,25,27,103]$ 
Table 2 Ethnomedicinal plant species with their uses and application procedure (Continued)

\begin{tabular}{|c|c|c|c|c|c|}
\hline Botanical name & Plant form & Used for & Parts used & Procedure & Reported cases \\
\hline $\begin{array}{l}\text { Oroxylum indicum } \\
\text { (L.) Kurz }\end{array}$ & Tree & Stomach pain & $\begin{array}{l}\text { Fruits, seed, } \\
\text { and bark }\end{array}$ & $\begin{array}{l}\text { Paste of hydrated fruit or seed or bark is } \\
\text { applied for stomach pain and chest pain } \\
\text { and is used as appetizer and against } \\
\text { jaundice. }\end{array}$ & $\begin{array}{l}\text { Jaundice, cuts and wounds, body pain, } \\
\text { liver problems, stomach pain, chest } \\
\text { pain, appetizer, asthma } \\
{[22,25-27,84,103,104]}\end{array}$ \\
\hline Phyllanthus emblica L. & Tree & $\begin{array}{l}\text { Stomach problem/ } \\
\text { gastritis }\end{array}$ & Fruit & $\begin{array}{l}\text { Dry paste or fruits are used to chew } \\
\text { or eat orally for stomach relief. }\end{array}$ & $\begin{array}{l}\text { Hair loss, stomach pain, liver problem } \\
{[23,26,27,103]}\end{array}$ \\
\hline Piper betle $\mathrm{L}$. & Climber & $\begin{array}{l}\text { Gastrointestinal } \\
\text { problems, cold, } \\
\text { and cough }\end{array}$ & $\begin{array}{l}\text { Leaves and } \\
\text { root }\end{array}$ & $\begin{array}{l}\text { Fresh leaf is chewed with beetle nut to } \\
\text { cure gastrointestinal problems, and dry } \\
\text { root is chewed whole day to cure } \\
\text { throat-related problems. }\end{array}$ & \\
\hline Piper nigrum L. & Climber & $\begin{array}{l}\text { Asthmatic problems, } \\
\text { cold, cough and } \\
\text { rheumatism }\end{array}$ & Seed & $\begin{array}{l}\text { Seeds are boiled with sugar and salt } \\
\text { and consumed three to four times a day } \\
\text { to control asthmatic problems, cold, } \\
\text { cough, and rheumatism. }\end{array}$ & $\begin{array}{l}\text { Cough and cold, asthma, constipation, } \\
\text { indigestion, throat infection }\end{array}$ \\
\hline Punica granatum L. & Tree & Increase blood & Fruit & Fresh fruits are eaten to increase blood. & $\begin{array}{l}\text { Nose bleeding, diarrhea, fever, } \\
\text { indigestion }[27,100,101,103,104]\end{array}$ \\
\hline $\begin{array}{l}\text { Rauvolfia serpentine } \\
\text { (L.) Benth. ex Kurz. }\end{array}$ & Herb & Fever & Root & $\begin{array}{l}\text { Leaf juice is used as a remedy for the } \\
\text { removal of opacities of cornea. Root } \\
\text { paste is applied on cuts, wounds, or } \\
\text { boils. Root infusion is given orally for } \\
\text { intestinal disorders. }\end{array}$ & $\begin{array}{l}\text { Paralysis, diabetes, fever, cuts and } \\
\text { wounds, pneumonia, jaundice, stomach } \\
\text { worm, dysentery, reliving hypertension } \\
\text { and blood pressure, intestinal disorder } \\
{[22,25,27,84,103,104]}\end{array}$ \\
\hline Streblus asper Lour. & Tree & Toothache & $\begin{array}{l}\text { Bark, latex } \\
\text { and root }\end{array}$ & $\begin{array}{l}\text { Tender stem is used as toothbrush } \\
\text { to cure toothache. }\end{array}$ & \\
\hline $\begin{array}{l}\text { Terminalia arjuna Roxb. } \\
\text { ex DC) Wight \& Arn. }\end{array}$ & Tree & Cardiac trouble & Bark & $\begin{array}{l}\text { Bark decoction is taken in empty } \\
\text { stomach to treat cardiac trouble. }\end{array}$ & $\begin{array}{l}\text { Asthma, heart problem, diabetes, } \\
\text { stomach disorder, appetizer, skin } \\
\text { disease, leucoderma, indigestion, chest } \\
\text { pain, tuberculosis, cardic trouble } \\
{[22,25,27,86,103,104]}\end{array}$ \\
\hline $\begin{array}{l}\text { Terminalia bellirica } \\
\text { (Gaertn.) Roxb. }\end{array}$ & Tree & $\begin{array}{l}\text { Dyspepsia } \\
\text { (indigestion) }\end{array}$ & Fruit & $\begin{array}{l}\text { Dried fruit is used to treat dyspepsia } \\
\text { and as cooling agent. }\end{array}$ & $\begin{array}{l}\text { Cough and cold, stomach disorder, } \\
\text { indigestion, gastroenteritis, skin diseases, } \\
\text { leucoderma, cooling agent, } \\
{[13,20,22,23,27,103]}\end{array}$ \\
\hline Terminalia chebula Retz. & Tree & Stomach problem & Fruit & Fruit is used against stomach disorder. & $\begin{array}{l}\text { Appetizer, cough and cold, } \\
\text { gastroenteritis, jaundice, pneumonia, } \\
\text { liver problems, indigestion, urinary } \\
\text { disorder, tonsillitis, } \\
\text { fever }[23,25,27,100,102,103,105]\end{array}$ \\
\hline $\begin{array}{l}\text { Tinospora sinensis } \\
\text { (Lour.) Merr. }\end{array}$ & Climber & $\begin{array}{l}\text { Rheumatism } \\
\text { and jaundice }\end{array}$ & Bark & $\begin{array}{l}\text { Bark is soaked overnight in water and is } \\
\text { consumed in the morning against } \\
\text { rheumatism and jaundice. }\end{array}$ & $\begin{array}{l}\text { Stomach pain, diabetes, rheumatism } \\
\text { and jaundice, urination, piles bleeding, } \\
\text { appetite, diarrhea } \\
{[22,27,100,101,103,104]}\end{array}$ \\
\hline Vitex negundo L. & Shrub & Whitening of hair & Leaf & Leaves prevent whitening of hair. & $\begin{array}{l}\text { Fever, gout, diarrhea, cardic disorder, } \\
\text { headache, bone fracture, body swelling } \\
{[22,27,83,90,103]}\end{array}$ \\
\hline $\begin{array}{l}\text { Zingiber officinale } \\
\text { Roscoe. }\end{array}$ & Herb & $\begin{array}{l}\text { Digestive, stimulant, } \\
\text { and cold and cough }\end{array}$ & Rhizome & Rhizome is used as digestive stimulant. & \\
\hline $\begin{array}{l}\text { Ziziphus mauritiana } \\
\text { Lam. }\end{array}$ & Tree & Vomiting & $\begin{array}{l}\text { Fruits and } \\
\text { seed }\end{array}$ & $\begin{array}{l}\text { Fruits and seeds are consumed } \\
\text { with salt to control vomiting. }\end{array}$ & \\
\hline
\end{tabular}

by $[79,80]$ among different dependent communities. The use of plants as food and medicine is common among Bengali women in Sylhet, Bangladesh [81]. On the regional scale, the maximum number of medicinal plants has been reported from Uttarakhand [82] followed by Sikkim and North Bengal [83]. The hill indigenous and aborigines of West Rarrh region of West Bengal use 46 plant species ethnomedicinally in the form of infusion, decoction, oil paste, and latex either as a sole drug or in combination to treat various ailments. A study reported that 91 species of medicinal plants are used for the treatment of skin disease by the indigenous population of Darjeeling Himalayas [83]. The Rava tribe of Jalpaiguri district of West Bengal has been reported to use 41 plant species as ethnomedicine [84]. The most frequently utilized plant parts are bark, leaves, roots, branches, stem, fruits, and seeds [22, 85, 86]. Additionally, some of them have medicinal value in their flowers, rhizomes, tubers, and wood. In some cases, the whole plant including the roots was utilized [22, 30]. Most of the ethnobotanical studies confirmed that the leaves are the major portion of the plant used in the treatment of 


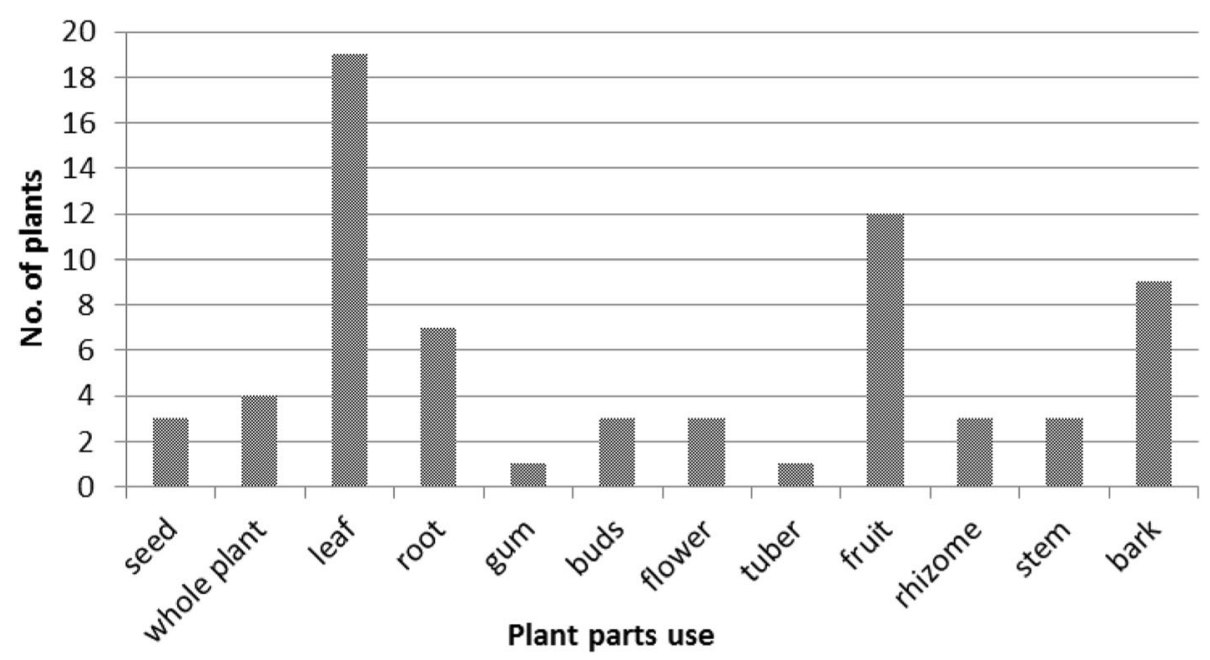

Fig. 3 Contribution of different plant parts to ethnomedicine

diseases [87-91]. We also compared these 53 medicinal plant species with the previously available literature and found 37 of them have also been reported earlier for their different uses from this region (Table 2).

\section{Use value, fidelity, informant consensus factor, and cultural importance index}

The range of use value for the documented species varied from the highest of 0.53 to the lowest of 0.006 (Table 1). The highest value of 0.53 was recorded for Ocimum sanctum followed by Centella asiatica (0.46) and Piper betle (0.28), and least value of 0.013 was observed each for Lennea coromandelica and Cinnamomum zeylanicum. The high use value (0.53) recorded for Ocimum sanctum in the study area may be due to the medico-religious significance among Hindu communities as has been described in their religious books. The highest UV was 0.48 for the species Zingiber officinale as ethnomedicinal plant has also been reported by [92] from Kurdistan, Iraq, and is in the reported range of results of the present study. Similar values of use value, for example, $0.51,0.53$, and 0.59 , on ethnomedicinal species have been reported by [93-95], respectively, from different regions of the globe and are in well support of the present study. The fidelity value (\%) of the species ranged from 2.29 to $93.75 \%$. The highest value of fidelity (93.75\%) was observed in Andrographis paniculata followed by Azadirachta indica (87.5\%) and Ocimum sanctum (89.6\%). The lowest value of fidelity $(2.70 \%)$ was observed in Streblus asper (Table 2). The high-value species is the important medicinal plant present in the home garden, and almost every informant was aware about its values. Studies of traditional agricultural systems in tropical regions of the world provide important information for understanding ecological processes associated with sustainable management of natural resources [96].

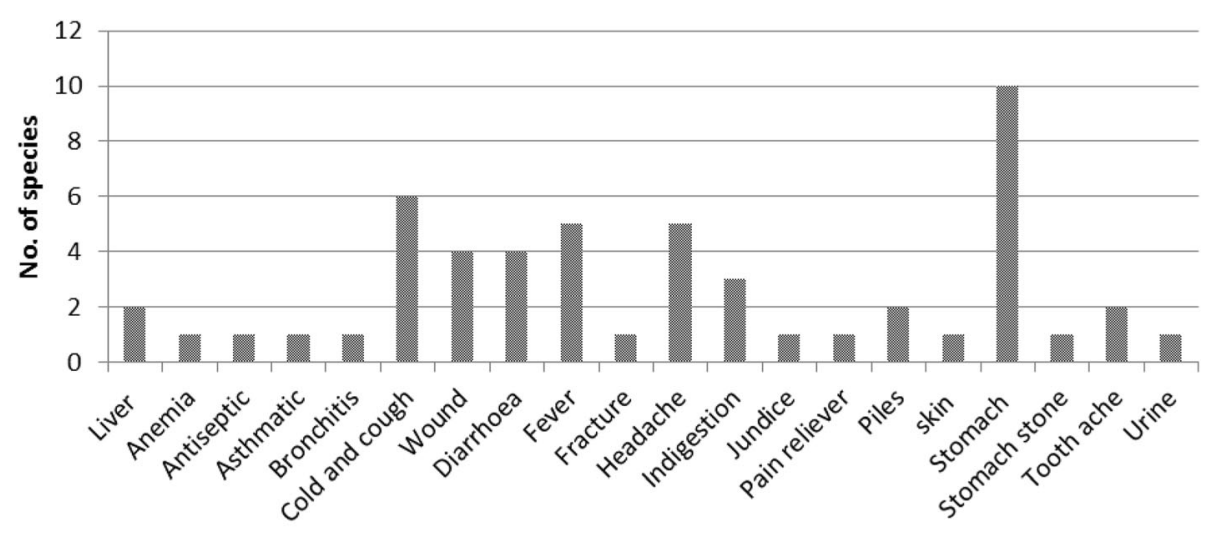

Diseases and ailment

Fig. 4 Number of species used to treat prevailing ailments in the area 
The reported use of medicinal plants was categorized into 20 broad diseases (Fig. 4) to identify species with a particular importance in culture (Fig. 5). The highest value of $F_{\text {ic }}$ was reported for indigestion and stomachache (0.98) followed by cold and cough (0.96). Lowest values of $F_{\text {ic }}(0.45)$ were recorded for skin diseases followed by bronchitis (0.64) and fever (0.67). Also, the highest $F_{\text {ic }}$ value of 0.96 has been reported for gastrointestinal diseases from Pakistan. Highest $F_{\text {ic }}$ values of 0.80 for gastrointestinal and kidney problems followed by respiratory infections (0.72) and skin infections (0.73) have also been reported by other authors [98]. The study conducted by [24] has also reported the highest number of species for diseases like indigestion and stomachache from the forest fringe communities of North Bengal. These ethnomedicinal plants are important elements of healthcare in the region and are regarded as important cultural components. The highest value of cultural importance (CI; 0.45$)$ was observed for Abroma augusta followed by 0.33 for Rauvolfia serpentina, Streblus asper, and Vitex negundo. The lowest value of CI (0.024) was observed for Emblica officinalis followed by 0.029 each for Euphorbia hirta and Hygrophila chulli. The cultural importance of medicinal plants has been reported by several authors throughout the globe [97-99] and hence can allow a resolution regarding the actual status of conservation of plants. The multiple uses of plant species for different diseases seem to be an important cause for the widespread adaptation of these medicinal plants. Ethnobotanical studies can further lead to a scientific assessment of the traditional medicines used which may provide a lead in drug development $[75,76]$. A detailed knowledge of the pharmacological effect of herbal drugs is therefore necessary for effective therapy of diseases. One of the major concerns regarding the use of herbal medicines is, however, their safe usage.

\section{Conclusion}

The reporting of 260 species of plant diversity and 53 species as medicinal plants from a cluster of a village is an important finding of diversity maintained by the home gardens. In addition, the documentation of ecological status and ethnomedicinal practices provided important knowledge for understanding the ecological processes and their sustainable management. The study clearly indicated that a wide range of local people is dependent on home gardens, and substantial number species with medicinal values are maintained in home gardens. These gardens act as conservation centers for many of these species. The results of the study confirm that household owners have good idea about the application of these medicinal plant parts. The application of ethnomedicine from the home garden also shows their role in maintaining the family healthcare system. These findings suggest that medicinal plants and folk medicines used by the communities in Cooch Behar district of West Bengal may be an initiation for further ethnomedicine research and could lead to the conservation of the medicinal flora. The woody trees in the garden apart from providing ethnomedicine also provide good opportunities for small-scale farmers to seize the carbon market opportunities in the future.

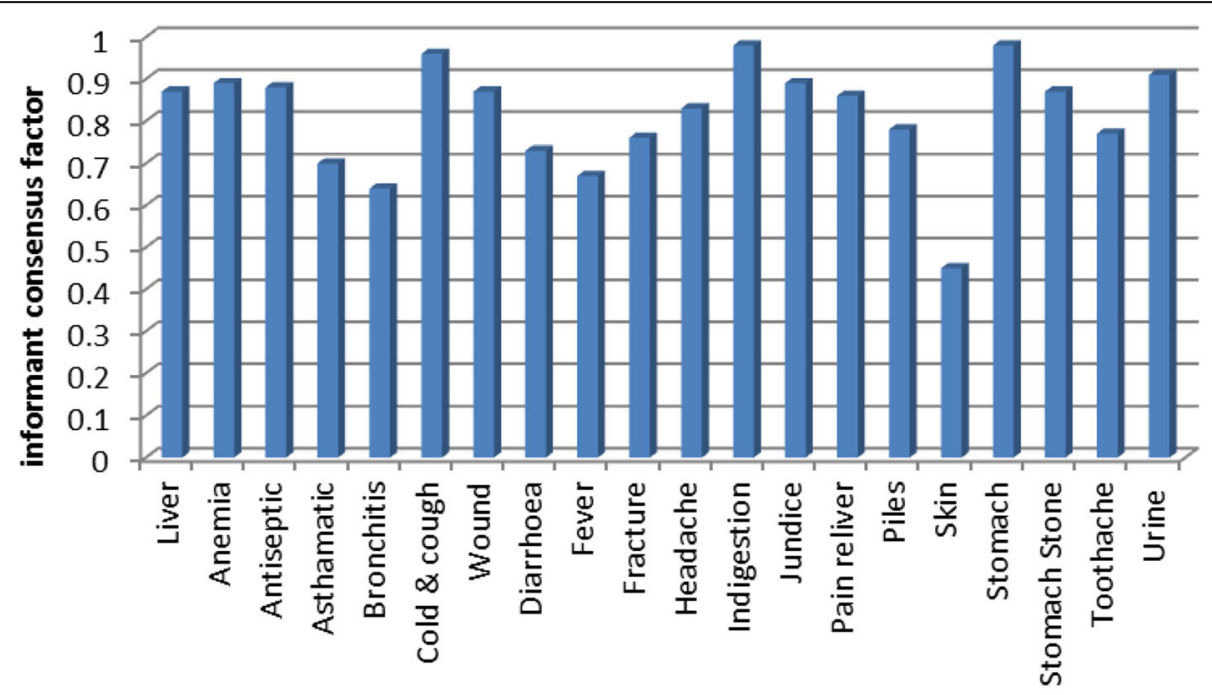

Name of the disease

Fig. 5 Values of informants consensus factor $\left(F_{\text {ic }}\right)$ for different disease category 


\section{Additional file}

Additional file 1: Table S1. Details of collected species as supplementary file. (DOCX $24 \mathrm{~kb}$ )

\section{Acknowledgements}

The financial help received from Science \& Engineering Research Board (SERB) through project (EMR/2016/001369) for the study is highly acknowledged. Authors are also thankful to the home garden owners for spending their valuable time and providing necessary information during the field survey.

\section{Funding}

Science \& Engineering Research Board (SERB) through project (EMR/2016/001369)

\section{Availability of data and materials}

The data and material is available from the first author.

\section{Authors' contributions}

NAP, BCS, GS, and SC designed the study, collected the data, and developed the manuscript. NAP, NC, SD, JAB, and SC improved the manuscript and restructured the data analysis. All authors read and approved the final manuscript.

\section{Ethics approval and consent to participate}

Prior oral informed consent was obtained from the local communities as well as from all individual participants.

\section{Consent for publication}

All authors gave consent for publication and there was no use of personal data in the paper.

\section{Competing interests}

The authors declare that they have no competing interests.

\section{Publisher's Note}

Springer Nature remains neutral with regard to jurisdictional claims in published maps and institutional affiliations.

\section{Author details}

'Department of Forestry, Uttar Banga Krishi Viswavidyalaya, Pundibari, WB, India. ${ }^{2}$ International Centre for Integrated Mountain Development (ICIMOD), GPO Box 3226, Kathmandu, Nepal. ${ }^{3}$ Department of Soil Science and Agricultural Chemistry, Uttar Banga Krishi Viswavidyalaya, Pundibari, WB, India. ${ }^{4}$ School of Agricultural Sciences and Forestry, College of Agriculture Fisheries and Forestry, Fiji National University, Koronivia, PO Box 1544 Nausori, Fiji Islands.

Received: 10 December 2018 Accepted: 31 January 2019 Published online: 19 February 2019

\section{References}

1. Panwar $\mathrm{P}$, Chakravarty S. Floristic structure and ecological function of homegardens in humid tropics of West Bengal, India. Indian J Agrofor. 2010; 12:69-78.

2. Gao J, He T, Li QM. Traditional home-garden conserving genetic diversity: a case study of Acacia pennata in Southwest China. Conserve Genet. 2012;13: $891-8$.

3. Ninez VK. Household gardens: theoretical considerations on an old survival strategy. Agric Syst. 1987;23:167-86

4. Christanty L. Homegardens in tropical Asia, with special reference to Indonesia. In: Landauer K, Brazil M, editors. Tropical homegardens. Tokyo.: The United Nations University Press; 1990. p. 9-20.

5. Lok R, editor. Huertos caseros tradicionales de America Central: características, beneficios e importancia desde un enfoque multidisciplinario. Turrialba: CATIE; 1998.

6. Anonymous. The economics of conserving agricultural biodiversity on-farm. Via dei Tre Denari 472/a 00057. Italy: International Plant Genetic Resources Institute Rome; 2002
7. Subba M, Pala NA, Shukla G, Chakravarty S. Inventory of flora in home gardens of sub-humid tropical landscapes, West Bengal, India. Int J Usufructus Mang. 2016;7(1):47-54

8. Subba M, Pala NA, Shukla G, Chakravarty S. Plant community structure of home gardens in eastern Himalayan foothill of West Bengal, India. Indian Forester. 2017;143:1265-74

9. Subba M, Pala NA, Shukla G, Pradhan K, Chakravarty S. Relationship of socioeconomic factors with attributes of homegarden agroforestry systems in northern part of West Bengal. J Tree Sci. 2017:36:76-91.

10. Subba M, Pala NA, Shukla G, Chakravarty S. Are size, distance and location responsible for species richness in home garden agroforestry systems? Indian Forester. 2017;143(3):223-7.

11. Subba M, Pala NA, Shukla G, Chakravarty S. Study of the variability of home gardens influencing carbon stock under sub-humid tropical zone of West Bengal, India. Indian Forester. 2018;144(1):60-6.

12. Galluzzi G, Eyzaguirre P, Negri V. Home gardens: neglected hotspots of agro-biodiversity and cultural diversity. Biodivers Conserv. 2010;19:3635-54

13. Fujisaka S, Wollenberg E. From forest to agroforest and from logger to agroforester: A case study. Agrofor Syst. 1991;14:113-29.

14. Martin GJ. Ethnobotany: a people and plants' conservation manual. London: Chapman \& Hall; 1995

15. Vogl-Lukasser B, Vogl CR. Ethnobotany as an interdisciplinary tool for the study of the biocultural management of agrobiodiversity in homegardens of Alpine farmers in Eastern Tyrol. In: Bottarin R, Tappeiner U, editors. Interdisciplinary mountain research. London: Blackwell; 2002. p. 264-73.

16. Tangjang $S$, Arunachalam A. Role of traditional home garden systems in Northeast India. IJTK. 2009;8:47-50.

17. Schaffert A, Ghorbani A, Martin K, Sauerborn J. Agro-biodiversity and its importance in home gardens of hill tribes in Xishuangbanna, SW China. In: Proceedings of International Conference Sustainable Land Use and Rural Development in Mountain Areas. Stuttgart: Hohenheim; 2012

18. Van der Merwea D, Swana GE, Botha CJ. Use of ethnoveterinary medicinal plants in cattle by Setswana-speaking people in the Madikwe area of the North West Province of South Africa. J S Afr Vet Assoc. 2001:72:189-96.

19. Lewis WH, Elwin Lewis MP. Medical botany plants affecting human health. New York: Wiley; 2003. p. 812.

20. Singh U, Lahiri N. Ancient India: new research. New Delhi: Oxford University Press; 2010

21. Kumar B, Vijayakumar M, Govindarajan R, Pushpangadan P. Ethnopharmacological approaches to wound healing-exploring medicinal plants of India. J Ethnopharmacol. 2007;114:103-13.

22. Shukla G, Chakravarty S. Ethnobotanical plant use of Chilapatta Reserved Forest in West Bengal. Indian Forester. 2012;138:1116-24.

23. Biswakarma S, Sarkar BC, Shukla G, Pala NA, Chakravarty S. Traditional application of ethnomedicinal plants in Naxalbari area of West Bengal, India Int J Usufruct Manag. 2015;16:36-42.

24. Biswakarma S, Pala NA, Shukla GV, Chakravarty S. Ethnomedicinal plants used to cure stomach disorders in forest fringe communities in northern part of West Bengal. Indian J Nat Prod Resour. 2017:8(4):370-80.

25. Bose D, Ghosh Roy J, Das Mahapatra S, Datta T, Das Mahapatra S, Biswas H. Medicinal plants used by tribals in Jalpaiguri district, West Bengal, India. Indian J Med Plants Stud. 2015;3:15-21.

26. Sarkar BC, Biswakarma S, Shukla G, Pala NA, Chakravarty S. Documentation and utilization pattern of ethnomedicinal plants in Darjeeling Himalayas, India. Int J Usufruct Manag. 2015;16:3-11.

27. Raj AJ, Biswakarma A, Pala NA, Shukla GV, Kumar M, Chakravarty S, Bussman RW. J Ethnobio Ethnomed. 2018:14(8):3-28. https://doi.org/10.1186/s13002018-0208-9.

28. Cotton CM. Ethnobotany: principles and applications. Chichester: Wiley; 1996.

29. Kar A, Goswami NK, Saharia D. Wild edible plants sold in the local market of Garo hills, Meghalaya. J Frontline Res Arts Sci. 2012;2:69-78.

30. Suresh CP, Bhutia KD, Shukla G, Pradhan K, Chakravarty S. Free list of wild edible fruit species of Sikkim Himalayas and their uses. In: Proceedings of the second International symposium on minor fruits and medicinal plants: 2013. p. 17-37.

31. Sathyavathi $R$, Janardhanan K. Wild edible fruits used by Badagas of Nilgiri District, Western Ghats, Tamil Nadu, India. J Med Plants Res. 2014;8:128-32.

32. Biswakarma S. Documentation and validation of ethnobotanical plant use in forest fringe area of Chillapatta forest division of West Bengal, Submitted to Uttar Banga Krishi Viswavidyalaya, Cooch Behar, West Bengal; 2016. p. 155. 
33. Mekonnen EL, Asfaw Z, Zewudie S. Plant species diversity of home garden agroforestry in Jabithenan District, North-Western Ethiopia. Int J Biodivers Conserv. 2014;6:301-7.

34. Johnson LM, Hunn ES. Introduction. In: Johnson LM, Hunn ES, editors. Landscape ethnoecology: concepts of biotic and physical space. New York and Oxford: Berghahn Books 9; 2010. p. 1-11.

35. Thomas E, Vandebroek I, Van Damme P, Goetghebeur P, Douterlungne D, Sanca S, Arrázola S. The relation between accessibility, diversity and indigenous valuation of vegetation in the Bolivian Andes. J Arid Env. 2009; 73:854-61.

36. Sõukand R, Kalle R. Herbal landscape: the perception of the landscape as a source of medicinal plants. Trames. 2010;14(64-59):207-26.

37. Folke C. Resilience: the emergence of a perspective for social-ecological systems analyses. Glob Env Change. 2006;16:253-67.

38. FSI, Indian State Forest Report. Forest Survey of India. Dehra Dun: Minintry of Environment and Forests \& Climate Change; 2017

39. Shinwari ZK, Gilani SS. Sustainable harvest of medicinal plants at Bulashbar Nullah, Astore (Northern Pakistan). J Ethnopharmacol. 2003;84:289-98.

40. Ekka R, Neeli DVK. Ethno-pharmacognostical studies of medicinal plants of Jashpur district, Chattisgarh. Int Jour Of Green Phar. 2007;1(1):2-4.

41. Jain SK. Ethnopharmacology and drug development. In: Chadwick DJ, March U, editors. Ethnobotany and search for new drugs, vol. 153. Chichester: Ciba Foundation symposium, 183 wiley; 1992

42. Jeyaprakash K, Ayyanar M, Geetha KN, Sekar T. Traditional uses of medicinal plants among the tribal people in Theni districts (Western Ghats), Southern India. Asian Pac J Trop Biomed. 2011;1:20-5.

43. Reddy BM. Wild edible plants of Chandrapur district, Maharastra, India. IJNPR. 2012;3:110-7.

44. Baroniya BM, NK S, SS B. Various ethno-medicinal plants of Malwa region used in stomach ailments. Int J Innov Res Dev. 2013;2(5):1662-71.

45. Census. District census handbook Koch Bihar, Directorate of census operations West Bengal.Series-20, Part XII-B. 2011.

46. Ray M, Rahaman M. Role of socio -cultural and economic characteristic on fertility choices in Cooch Behar district, West Bengal. AJSSH. 2017;7(9):202-10.

47. Caballero-Serrano V, Onaindia M, Alday JG, Caballero D, Carrasco JC, McLaren B, Amigo J. Plant diversity and ecosystem services in Amazonian homegardens of Ecuador. Agric Ecosyst Environ. 2016;225:116-25.

48. Zemede A, Ayele N. Homegardens in Ethiopia: characteristics and plant diversity. SINET: Ethiopian J Sci. 1995;18:235-66.

49. Zemede A. Survey of indigenous food crops and useful plants, their preparations and homegardens in Ethiopia. Indigenous African food crops and useful plants. Resource Utilization, Assessment series, No. B6. UNU, ICIPE Press. 1997.

50. Dey T, Pala NA, Shukla G, Pal PK, Das G, Chakravarty S. Climate change perceptions and response strategies of forest fringe communities in Indian Eastern Himalaya. Env Devt Sustde. 2017. https://doi.org/10.1007/s10668017-9920-1.

51. Dey T, Pala NA, Shukla G, Pal PK, Chakravarty S. Perception on impact of climate change on forest ecosystem in protected area of West Bengal, India. JFES. 2017;33:1-7. https://doi.org/10.7747/JFES.2017.33.1.1.

52. Suleiman MS, Wasonga VO, Mbau JS, Suleiman A, Elhadi YA. Non-timber forest products and their contribution to household's income around Falgore Game Reserve in Kano, Nigeria. Ecol Process. 2017;6:23. https://doi. org/10.1186/s13717-017-0090-8.

53. Curtis JT. Vegetation of Wisconsin. Madison: Wisconsin Press; 1959.

54. Ferreira FS, Brito SV, Ribeiro SC, Almeido WO, Alves RRN. Zoo therapeutics utilized by residents of the community Poco Dantas, Crato-CE, Brazil. J Ethnobio Ethnomed. 2009;5:21

55. Alexiades MN, Sheldon JW. Selected guidelines for ethnobotanical research: a field manual. Bronx: New York Botanical Garden Press; 1996.

56. Ragupathy S, Steven NG, Maruthakkutti M, Velusamy B, Huda MMU. Consensus of the 'Malasars' traditional aboriginal knowledge of medicinal plants in the Velliangiri holy hills, India. J Ethnobiol Ethnomed. 2008;4(1):8.

57. Tardio J, Pardo-de-Santayana M. Cultural importance indices: a comparative analysis based on the useful wild plants of Southern Cantabria. Econ Bot. 2008;62(1):24-39.

58. Hodgkin T. Home gardens and the maintenance of genetic diversity. In: Watson JW, Eyzaguirre PB, editors. Proceeding of the second international home garden workshop. Rome: Biodiversity International; 2001. p. 14-8.

59. Agbogidi OM, Adolor EB. Home gardens in the maintenance of biological diversity. Appl Sci Rep. 2013;1:19-25.
60. Larios C, Casas A, Vallejo M, MorenoCalles Al, Blancas J. Plant management and biodiversity conservation in Náhuatl homegardens of the Tehuacán Valley, Mexico. J Ethnobio Ethnomed. 2013;9:74-89.

61. Kumari MAS, Kansuntisukmongkol K, Brockelman WY. Plant diversity in home gardens and its contribution to household economy in suburban areas in Sri Lanka. Environ Nat Resour J. 2009;7:12-30.

62. Kala CP. Home gardens and management of key species in the Pachmarhi Biosphere Reserve of India. J Biodivers. 2010;1:111-7.

63. Subba M. Study of the variability of home gardens influencing carbon stock under Terai region of West Bengal: Master thesis, Uttar Banga Krishi Viswavidyalaya; 2014. p. 166.

64. Subba M, Sarkar BC, Pala NA, Shukla G, Vineeta, Chakravarty S. Species diversity, size and component arrangement in home gardens of North Bengal, India. Ind J Agroforestry. 2018;20(2):1-5.

65. May PH, Anderson AB, Balick MJ, Frazao MF. Subsistence benefits from the babassu palm (Orbignya martiana). Econ Bot. 1985;3:113-29.

66. Asare EO, Oppong SK, Twum-Ampofo K. In: Landauer K, Brazil M, editors. Homegardens in the humid tropics of Ghana. In: Tropical homegardens. Tokyo: United Nations University; 1990. p. 80-93.

67. Okigbo BN. Home gardens in Tropical Africa. In: Landauer K, Brazil M, editors. Tropical homegardens. Tokyo: United Nations University Press; 1990. p. 41-65.

68. Nuberg Kl, Evans DG, Senanayake R. Future of forest gardens in the Uvan uplands of Sri Lanka. Environ Manag. 1994;18:794-813.

69. Falanruw MVC. The food production system of the Yap Islands. In: Landauer K, Brazil M, editors. Tropical homegardens. Tokyo: United Nations University; 1990. p. 94-104.

70. Mitchell R, Hanstad T. Small home garden plots and sustainable livelihoods for the poor: Rural Development Institute (RDI), Livelihood Support Programme (LSP), FAO; 2004. p. 1-43.

71. Egodawatta C, Warnasooriya R. Diversity of tree flora in homegardens in urban proximity of Anuradhapura city, Sri Lanka. Agricul For Fisher. 2014;3:34-9.

72. Pavia R, Barbagiovanni MI, Strada GD, Piazza MG, Engel P, Fideghelli C. Autochthonous fruit tree germplasm at risk of genetic erosion found in home gardens in the region of Latium (Italy). In: Proceedings of a workshop on crop genetic resources in European home gardens. Rome: Biodiversity international; 2009. p. 21-5.

73. Amjad MS, Arshad M, Qureshi R. Ethnobotanical inventory and folk uses of indigenous plants from Pir Nasoora National Park, Azad Jammu and Kashmir. Asian Pac J Trop Biomed. 2015;5:234-41.

74. Anand SP, Deborah S. Enumeration of wild edible fruits from Boda hills and Kolli hills. Int J Appl Biol Pharm. 2016;7:96-102.

75. Rout SM, Choudary KA, Kar DM, Das L, Jain A. Plants in traditional medicinal system- future source of new drugs. Int J Pharm Pharm Sci. 2009;1:1-23.

76. Ghosh A. Herbal folk remedies of Bankura and Medinipur districts, West Bengal. IJTK. 2003;2:393-6.

77. Kesari AN, Gupta RK, Singh SK, Diwakar S, Watal G. Hypoglycemic and antihyperglycemic activity of Aegle marmelos seed extract in normal and diabetic rats. J Ethnopharmacol. 2006;107:374-9.

78. Mishra BB, Singh DD, Kishore N, Tiwari VK, Tripathi V. Antifungal constituents isolated from the seeds of Aegle marmelos. Phytochemistry. 2010;71:230-4.

79. Kosalge SB, Fursule RA. Investigation of ethnomedicinal claims of some plants used by tribals of Satpuda Hills in India. J Ethnopharmacol. 2009;121: 456-61.

80. Namsa ND, Tag H, Mandal M, Kalita P, Das AK. An ethnobotanical study of traditional anti-inflammatory plants used by the Lohit community of Arunachal Pradesh, India. J Ethnopharmacol. 2009;125:234-45.

81. Jennings HM, Merrell J, Thompson JL, Heinrich M. Food or medicine? The food-medicine interface in households in Sylhet. J Ethnopharmacol. 2015; 167:97-104.

82. Kala CP. Indigenous uses, population density and conservation of threatened medicinal plants in protected areas of the Indian Himalayas. Conserv Bio. 2005;19:368-78.

83. Ghosh A. Ethnomedicinal plants used in West Rahrr region of West Bengal. Nat Prod Rad. 2008;75:461-5

84. Bose D. An ethno-medicobotanical investigation among Rava tribe of Jalpaiguri district. NBU J Plant Sci. 2011;5:61-5.

85. Alagesaboopathi C. Medicinal plants used by tribal and non-tribal people of Dharmapuri district, Tamil Nadu, India. IJCRBP. 2014;1:64-73.

86. Mondal T, Samanta S. An ethnobotanical survey on medicinal plants of Ghatal block, West Midnapur District, West Bengal, India. IJCRBP. 2014;1:35-7. 
87. Rajendran SM, Chandrasekar K, Sundaresan V. Ethnomedicinal lore of Valaya tribe in Seithur hills of Virudhunagar district, Tamil Nadu, India. IJTK. 2014;1:59-71.

88. Mahishi P, Srinivasa BH, Shivanna MB. Medicinal plant wealth of local communities in some villages in Shimoga District of Karnataka, India. J Ethnopharmacol. 2005;98:307-12.

89. Jagtap SD, Deokule SS, Bhosle SV. Some unique ethnomedicinal uses of plants used by the Korku tribe of Amravati district of Maharashtra, India. J Ethnopharmacol. 2006;107:463-9.

90. Ignacimuthu S, Ayyanar M, Sankara SK. Ethnobotanical study of medicinal plants used by Paliyar tribals in Theni district of Tamil Nadu, India. Fitoterapia. 2008;79:562-8.

91. Choudhury S, Sharma P, Dutta Choudhury M, Dutt SG. Ethnomedicinal plants used by Chorei tribes of Southern Assam, North Eastern India. Asian Pac J Trop Dis. 2012:141-7.

92. Gairola S, Sharma S, Bedi YS. A cross cultural analysis of Jammu, Kashmir and Ladakh India. Medicinal Plant Use. 2014;155:925-86.

93. Özdemir E, Alpınar K. An ethnobotanical survey of medicinal plants in western part of central Taurus Mountains: Aladaglar (Nigde-Turkey). J Ethnopharmacol. 2015;166:53-65.

94. Tetik F, Civelek S, Cakilcioglu U. Traditional uses of some medicinal plants in Malatya (Turkey). J Ethnopharmacol. 2013;146:331-46.

95. Polat R, Cakilcioglu U, Satl F. Traditional uses of medicinal plants in Solhan (Bingöl Turkey). J Ethnopharmacol. 2013;148:951-63.

96. Gliessman S. Agroecología: Procesos Ecológicos en Agricultura Sostenible. Turrialba: LITOCAT; 2002.

97. Mussarat S, Abdel-Salam NM, Tariq A, Wazir SM, Ullah R, Adnan M. Use of ethnomedicinal plants by the people living around Indus river. J Evid Based Complementary Altern Med. 2014;6:14.

98. Heinrich M, Ankli A, Frei B, Weimann C, Sticher O. Medicinal plants in Mexico: healers' consensus and cultural importance. Soc Sci Med. 1998;47: 1859-71.

99. Tudela-Talavera P, La-Torre-Caudros MDLA. Cultural importance and use of medicinal plants in Shipibo-Conibo native community of Vencedor (Loreto) Peru. Ethnobot Res Appl. 2016;14:533-48.

100. Yonzone R, Bhujel RB, Rai S. Genetic resources, current ecological status and altitude wise distribution of medicinal plants diversity of Darjeeling Himalaya of West Bengal, India. Asian Pac J Trop Med. 2012;2:S439-45.

101. Yonzone R, Rai S, Bhujel RB. Ethnomedicinal and aromatic plant diversity and resources of Darjeeling district of eastern Himalaya in India. Int J Adv Pharm Res. 2012;3:859-71.

102. Malla B, Chhetri RB. Ethnoveterinary practices of some plant species by ethnic people of Parbat district, Nepal. Kathmandu Univ J Sci Eng Technol. 2012;8:44-50,

103. Vineeta, Pala NA, Shukla G, Chakravarty S. Traditionally used medicinal plants for treatment of stomach disorder in West Bengal, India. A scruting and analysis from secondary literature. Stud Ethno-Med. https://doi.org/10.1080/ 09735070.2018.1444454.

104. Mathur A, Joshi H. Ethnobotanical studies of the Terai region of Kumaun, Uttarakhand, India. Ethnobot Res Appl. 2013;11:175-203.

105. Sinhababu A, Banerjee A. Ethno-botanical study of medicinal plants used by tribals of Bankura district, West Bengal, India. J Med Plants Stud. 2013;1:98-104.

Ready to submit your research? Choose BMC and benefit from:

- fast, convenient online submission

- thorough peer review by experienced researchers in your field

- rapid publication on acceptance

- support for research data, including large and complex data types

- gold Open Access which fosters wider collaboration and increased citations

- maximum visibility for your research: over $100 \mathrm{M}$ website views per year

At BMC, research is always in progress.

Learn more biomedcentral.com/submissions 